
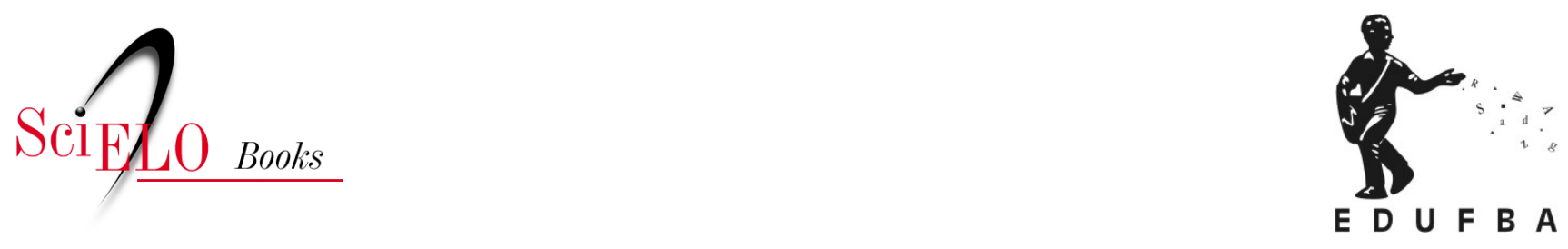

2. "Escrevivendo" uma região e um samba de roda

\author{
Nerivaldo Alves Araújo
}

ARAÚJO, N.A. "Escrevivendo" uma região e um samba de roda. In: Poética oral do samba de roda das margens do Velho Chico [online]. Salvador: EDUFBA, 2016, pp. 43-69. ISBN: 978-85-232-2031-0. https://doi.org/10.7476/9788523220310.0003.

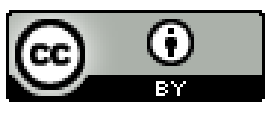

All the contents of this work, except where otherwise noted, is licensed under a Creative Commons Attribution 4.0 International license.

Todo o conteúdo deste trabalho, exceto quando houver ressalva, é publicado sob a licença Creative Commons Atribição $\underline{4.0}$. 
Ny
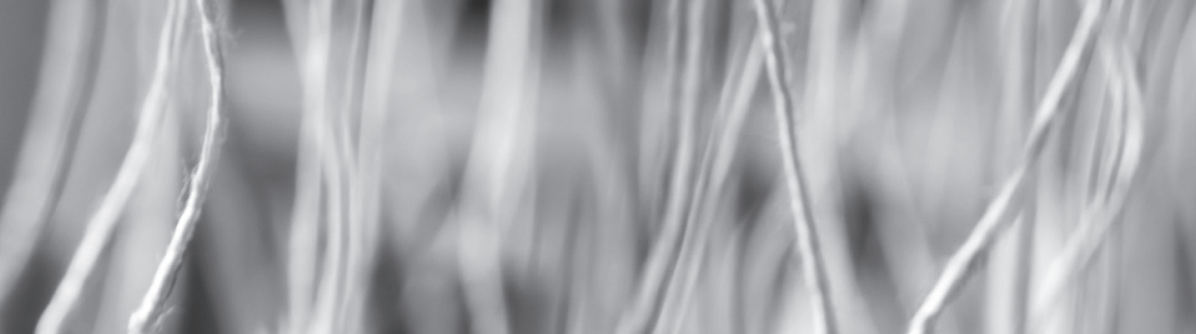


\section{"Escrevivendo" uma região e um samba de roda}

A região de Xique-Xique carrega, em si, uma excentricidade natural. Trata-se de um lugar de muitas histórias e muitos encantos, retratados pelo seu povo, através da poética oral do samba de roda e demais expressões da cultura ribeirinha, que se manifestam sob as mais diversas maneiras.

Antes de seguir esse curso, no qual se descrevem imagens, histórias e particularidades de uma região, seu samba e comunidade poética, faz-se oportuno considerar que a expressão "escrevivendo", trazida no título deste capítulo, foi tomada de empréstimo da escritora e poetisa Conceição Evaristo, para demonstrar que, assim como a autora, nessa viagem poética, ao desenvolver essa pesquisa para escrever tais relatos, o autor acabou vivenciando muitas das histórias narradas e, ainda, pôde sentir-se como um dos sambadores, integrantes da comunidade poética das margens do Velho Chico, pois a pisadinha do samba de roda em estudo envolve, atrai, inclui, sendo quase impossível ficar de fora da roda cultural.

Para reforçar tal ideia, retomam-se as palavras da própria autora sobre sua "escrevivência”, extraídas do texto "Conceição Evaristo por Conceição Evaristo”, encontrado no Portal Literafro da Universidade Federal de Minas Gerais (UFMG), na seção de escritores:

Escrevo. Deponho. Um depoimento em que as imagens se confundem, um eu agora a puxar um eu menina pelas ruas de Belo Horizonte. E como a escrita e o viver se con(fundem), sigo eu nessa escrevivência a lembrar de algo que escrevi recentemente: 'O olho do sol batia sobre as roupas estendidas no varal. E mamãe sorria feliz. Gotículas de água aspergindo a minha vida-menina balançavam ao vento. Pequenas lágrimas dos lençóis. Pedrinhas azuis, pedaços de anil, fiapos de nuvens solitárias caídas do céu eram encontradas ao redor das bacias e tinas das lavagens de roupa. Tudo me causava uma 
comoção maior. A poesia me visitava e eu nem sabia.... (EVARISTO,

2009, grifo nosso)

Localizada nas margens do Velho Chico, a cidade de Xique-Xique tem uma relação muito particular com o rio. Não há como negar que, assim como a história do surgimento da cidade, a vida de sua gente encontra-se diretamente ligada a esse cenário que também se faz personagem principal das suas histórias, do seu imaginário, sempre presente nas memórias e tradições ribeirinhas.

Em suas narrativas, os moradores apresentam a história do próprio município, dos tempos áureos, em que o Rio São Francisco constituía-se, praticamente, na única via de transporte, fazendo-se considerá-lo como o principal caminho que proporcionou a colonização (ainda que essa tenha causado tantas tragédias de ordem social) e o crescimento da região, pois se sabe que foi a melhor - ou talvez a única - forma de acesso a algumas áreas recônditas do sertão.

No rio, transitaram o aprisionamento e a libertação. Por um lado, desde o início do processo de colonização do Brasil, houve investimentos, por parte do governo, em expedições colonizadoras, com o objetivo de descobrir riquezas minerais, aprisionar índios para usá-los na lavoura e garantir o povoamento do sertão nordestino. Por outro, o Velho Chico foi inspiração de resistência, pois os povos das suas margens sempre se mantiveram ligados às suas águas, que carregam consigo a memória, a história dos seus antepassados, dos momentos de glória, dos grandes vapores, da riqueza econômica e cultural que representara. Em suas margens, a vida do ribeirinho é tecida, assim como suas redes de pesca, em estreita ligação com o rio, o qual se constitui como fator preponderante de subsistência, sustentando suas tradições e seu imaginário.

\section{História e localização do município de Xique-Xique}

O samba de roda das margens do Velho Chico coexiste em um cenário, no qual as belezas naturais dominam toda a paisagem da região ribeirinha. Vale destacar, inicialmente, a exuberância da caatinga, que ora se apresenta seca, empoeirada e aparentemente sem vida, devido à falta das chuvas no período da estiagem, mas que ora renasce verdejante, iluminada, cheia de cores, movimentos e dos sons da fauna com seus pássaros, borboletas, lagartos e outras espécies animais. 
Assim é a caatinga quando a chuva cai, podendo ser comparada a uma pintura viva da natureza, com seus arbustos exuberantes, exalando o perfume de suas flores, colorindo o sertão. Neste cenário, destaca-se uma espécie de cacto que, segundo informações retiradas do site do IBGE, recebe o nome de "xique-xique”, motivando a origem do topônimo, ou seja, do nome da cidade.

A caatinga margeia toda a extensão do Rio São Francisco, na região de XiqueXique, indo beber de suas águas, cedendo espaço, por diversas vezes, a dunas de areia branca, que surgem em suas margens e se movem ao sabor dos ventos e das águas. Apesar de, em algumas partes, a realidade nos mostrar a degradação das margens, a falta de mata ciliar e de investimentos do poder público na revitalização do rio, a região ainda nos proporciona as mais belas imagens de uma natureza peculiar, que, assim como as tradições do seu povo, luta para se manter viva em meio a tanta adversidade.

Essa paisagem paradisíaca pode ser contemplada na viagem feita pela poética oral ribeirinha, até a região do Mocambo dos Ventos, povoado situado no município de Barra, na divisa com Xique-Xique, cujo limite é o rio. Esse também é um lugar cuja singularidade fascina, tanto pelos encantos naturais das dunas moventes de areia branca que se misturam ao azul do céu de um lado e ao brilho das águas ensolaradas do outro, quanto pela história, simplicidade e pelo acolhimento de seu povo.

Assim como em toda a região, esse povoado apresenta uma história de reminiscência quilombola, pois os próprios moradores, ao contar a história do surgimento do lugar, ressaltam que os primeiros habitantes foram negros escravizados, os quais vieram fugidos e se estabeleceram no local, formando uma espécie de quilombo.

Em relação ao nome Mocambo dos Ventos, o vocábulo “mocambo” tem sua significação, conforme o Michaelis Moderno Dicionário da Língua Portuguesa, constituída como o lugar no qual os escravizados se recolhiam quando fugiam para o mato, habitação comum, sem nenhum conforto. (WEISFLOG, 2009) Como o vento se faz presente durante todas as horas, todos os dias e meses do ano, os próprios moradores explicam que, por isso, o lugar passou a ser chamado assim.

Dessa maneira, toda a margem do Velho Chico, na região de Xique-Xique, assume características de um grande quilombo, de um mocambo, onde não apenas o fenótipo dos ribeirinhos, mas também suas tradições são, em grande parte, afrodescendentes. Neste lugar de memória, nas mesmas águas, navegam 
elementos da tradição de povos de origem africana, que se misturam com outras marcas culturais, gerando uma diversidade, causada pela confluência com a cultura indígena e a do colonizador português.

Viajar pelo rio permite contemplar as suas maravilhas e os seus encantos. Em qualquer viagem que se faça, navegando em suas águas, pode-se testemunhar os caprichos da natureza. Imagens paradisíacas se multiplicam à vista, a exemplo do pôr do sol, momento de rara beleza ao entardecer nas águas do Velho Chico.

As "c'roas"7 que surgem no leito do rio no período de estiagem formam belas praias naturais, onde é possível passar o dia sob um céu azul ensolarado, banhando-se em águas refrescantes. Nesses lugares, é comum encontrar pescadores que aportam, passando o dia com suas famílias em atividades de pesca e de lazer.

Na região, o rio tem um papel fundamental na locomoção dos pescadores, dos povos ribeirinhos. Por todo o seu leito, é comum encontrar barcos e canoas transportando pessoas, mercadorias e o próprio pescado para a sede do município de Xique-Xique. O transporte escolar dos estudantes residentes nas ilhas e margens é feito também por meio de barcos, bem como o transporte de professores que trabalham nessas localidades. Podem-se encontrar, navegando pelo curso do rio, vários tipos de embarcações, desde pequenas e rudimentares canoas, geralmente movidas a remo e velas precárias, até barcos maiores, movidos a motor, com capacidade para cerca de 20 pessoas.

É assim o cotidiano do ribeirinho, cuja lida diária se constitui basicamente da pesca. Aqueles que têm pequenos pedaços de terra praticam a agricultura de subsistência e o criatório de animais domésticos como porcos, galinhas e alguns caprinos, ovinos e bovinos. A grande maioria possui profissão registrada em carteira como pescador e recebem do Governo Federal uma bolsa de auxílio durante os meses em que a pesca é proibida no rio, devido ao período de reprodução dos peixes, chamado de defeso. A renda desses pescadores é complementada, ainda, pelo Programa Bolsa Família, do Governo Federal.

7 Espécie de pequenas ilhas formadas por bancos de areia no meio do leito do rio, quando a sua vazão baixa, em que os pescadores costumam aportar para pescar. Também é utilizada pelas pessoas para passeios e banhos. A palavra original é "coroa", mas sofre uma transformação linguística para "c'roa", ou seja, é uma variante local da palavra "coroa". 
Como se pode ver, na região, não há atividades econômicas de grande impacto, como indústrias ou projetos de pesca e de agricultura amparados pelo governo, no intuito de incentivar a permanência e a melhoria da vida do ribeirinho. Os sujeitos que fazem parte do grupo de sambadeiras e sambadores vivem de maneira simples, mas com grande riqueza e diversidade cultural, as quais podem ser percebidas nas várias manifestações de sua cultura popular.

Como parte desse cenário, é preciso retratar a Ilha do Miradouro, que fica próxima à sede do município. A colonização da região tem a referida ilha como parte importante desse processo de povoamento. Segundo a história retratada em sites, como o do IBGE e o da própria prefeitura da cidade de Xique-Xique, tudo começou por lá. A ilha está localizada a cerca de dois quilômetros da cidade de Xique-Xique, sendo que, para chegar lá, gastam-se, aproximadamente, 20 minutos de barco, rio acima. Possui uma população estimada em cerca de 280 habitantes, segundo o censo (2010) do IBGE, praticamente todos vivendo da pesca e possuindo algum laço de parentesco.

Quanto ao seu nome, conta a história que, da ilha, dava para mirar o brilho do ouro da Serra do Assuruá, onde se localiza, atualmente, o município de Gentio do Ouro. Tal fato reforça o significado do nome "miradouro", que, segundo o Michaelis Moderno Dicionário da Língua Portuguesa (WEISZFLOG, 2009), corresponde a um ponto elevado de onde se descobre largo horizonte. Desse modo, da ilha, pode-se contemplar todo o horizonte, inclusive a referida serra, onde se dizia que o ouro costumava brilhar.

O imaginário da região revela, dentre muitas, uma narrativa de que, nesta ilha, uma serpente vive nas profundezas das águas próximas à igreja de Nossa Senhora Santana.

Todos conhecem essa lenda. Segundo os próprios moradores contam, havia uma moça, filha de um fazendeiro rico, que teve um filho de um tropeiro, escondendo a gravidez e jogando o filho recém-nascido no rio. Esse filho se transformou numa cobra e vivia no rio. Numa missa celebrada durante as Santas Missões, o mistério foi revelado: uma cobra entrou na igreja e foi aninhar-se no colo de uma mulher, sua mãe, mamando em seu seio e se transformando novamente em uma criança. Neste momento, houve o revés: a mãe transformouse numa serpente enfurecida que foi trancafiada nos porões da referida igreja. Conta a lenda que, em algumas noites, ainda é preciso que os moradores rezem 
o Ofício de Nossa Senhora para acalmar a serpente, a qual costuma esbravejar nas profundezas das águas do rio. ${ }^{8}$

Essa narrativa faz parte da literatura oral ribeirinha, demonstrando quão rica é a cultura local, que se manifesta sob as mais variadas formas, sendo, no caso deste estudo, através do samba de roda, o qual, em suas cantigas, demonstra todo um universo de encanto e de representação do cotidiano com suas histórias, costumes e tradições.

A região delimitada como espaço de pesquisa localiza-se no município de Xique-Xique, no estado da Bahia, o qual está situado, conforme informações do IBGE, a $587 \mathrm{Km}$ da capital Salvador, na margem direita do Rio São Francisco, na mesorregião do Vale do São Francisco da Bahia e na microrregião de Barra. Limitase com os municípios de Itaguaçu da Bahia, Gentio do Ouro, Ipupiara, Morpará, Barra, Pilão Arcado e Sento Sé. Possui uma área territorial de 5.200,809 km² e população de 45.536 habitantes. (CENSO, 2010)

De acordo com dados históricos do IBGE (2013), muito antes da colonização, a região era habitada pelos índios cariris, massacarás, pontás, aracajás e amoipiras. O seu povoamento ocorreu no início do século XVI, quando, por volta da década de 1540, sertanistas, à procura de ouro, iniciaram o desbravamento do Vale do São Francisco. Formaram-se fazendas à margem direita do rio, em terras basicamente pertencentes às famílias Casa da Ponte e Mestre de Campo Guedes de Brito.

Já na segunda metade do século XVII, em terras do coronel Garcia D’Ávila, conde da Casa da Ponte, surgiu um arraial localizado na Ilha do Miradouro, na qual foi construída a capela de Nossa Senhora Santana, para atender aos anseios dos seus devotos, a mando da viúva do coronel Garcia D’Ávila.

Mais tarde, em terra firme, construiu-se a capela de Senhor do Bonfim à margem da Ipoeira, ${ }^{9}$ na fazenda Praia, de propriedade de Sebastião José de Carvalho, originando um novo núcleo populacional, inclusive composto de alguns moradores da Ilha do Miradouro, que se mudaram para o local.

Depois de ser elevada à categoria de vila, passou à condição de cidade, com a denominação de Chique-Chique, pela Lei Estadual n. ${ }^{\circ}$ 2.082, de 13 de junho de

8 Ver trabalho do próprio autor, intitulado Navegando nas margens: narrativas orais do Velho Chico, o qual traz algumas versões narradas pelos próprios moradores sobre a serpente da llha do Miradouro. Disponível em: <http://www.ppgel.uneb.br/wp/wp-content/uploads/2011/og/araujo_neri.pdf>.

9 Variação regional da palavra "empoeira". 
1928. Atualmente, o nome é grafado como Xique-Xique, depois de ter sido alterado através de Decreto-lei Estadual n. ${ }^{\circ}$ 141, de 31 de dezembro de 1943, retificado pelo Decreto Estadual n. ${ }^{\circ} 12.978$, de 1 de junho de 1944.

O processo de colonização foi marcado, assim como na maior parte do país, pela presença da Igreja Católica, que buscava a catequização dos índios e demais habitantes da região. Assim, era frequente a construção de capelas e a realização das Santas Missões, ${ }^{10}$ nas quais, deslocava-se para as regiões certo número de padres e missionários, com o intuito de evangelizar, de formar a conduta moral e religiosa do povo, instituindo, assim, uma ideologia cristã, de base eurocêntrica.

Esse processo de colonização surgiu com a construção, ao longo do rio, de currais a cada 20 léguas, aproximadamente, e deixando um casal de negros escravizados, alguns novilhos e equinos. Por volta de 1649 , tendo começado pela foz do rio, Francisco Garcia D’Ávila e seus homens chegaram à região do Miradouro. Vale considerar, desde já, que essa maneira de colonização da região com a utilização de fazendas e de mão de obra escrava veio contribuir para a forte presença, na região, da cultura afrodescendente com suas marcas étnico-raciais. Os Garcia D’Ávila, conhecidos pela sua riqueza latifundiária, foram figuras da nobreza branca que marcaram a história da escravidão na Bahia com a tinta do sangue negro, tendo sido o seu castelo (uma das suas residências, localizada nas imediações da Praia do Forte, Bahia) um local marcado pela dor, por histórias de castigos cruéis, empalações e todo tipo de tortura aos que lhes serviram como escravos. Presume-se que, na região do Miradouro, a conduta dessa nobre família não tenha sido tão diferente. A fim de resistir às dores físicas e psicológicas causadas pela escravidão, cantar e dançar talvez tenham sido, então, eficientes estratégias de sobrevivência dos sujeitos aqui escravizados, herdadas dos seus ascendentes, legadas aos seus descendentes. Neste texto, mais adiante, o batuque e outros gêneros musicais africanos apresentam-se como influenciadores do samba brasileiro.

Dessa forma, o samba de roda faz parte do universo cultural das margens do Velho Chico, e a sua origem apresenta-se atrelada à própria história do lugar. Passa, assim, consoante Santos (2012), a se constituir num documento da me-

10 Muito comum na região a realização, desde a colonização, das Santas Missões, espécie de pregações, palestras e celebrações dirigidas ao povo cristão, com o intuito de reforçar a fé e a vida cristã. Até hoje, é comum a chegada, na região, de grupos de cristãos formados de padres, freiras, bispos e missionários, com o intuito de evangelizar. 
mória coletiva, carregando em si, igualmente a todo texto oral, certos elementos formais como o ritmo, a enumeração e a repetição, considerados fundamentais para a sua preservação. É a história do samba das margens, que, conforme se pode observar, navega por diferentes águas, numa região cuja colonização se deu com a presença do negro, do índio e do branco.

\section{Tecendo as redes da história do samba de roda no Brasil e nas margens do Velho Chico, região de Xique-Xique}

Não se pode falar do samba, seu percurso histórico, significações e tipologias sem, antes, considerar que não existe um consenso entre os diversos estudiosos que tratam desses aspectos. Assim sendo, propõe-se trazer um apanhado histórico, conceitual e tipológico do samba e sua poética, amparando-se numa diversidade de informações apresentadas por vários autores da área, com o intuito de disponibilizar um conhecimento necessário para que se possa ter uma visão satisfatória dessa manifestação poética tão expressiva que integra a cultura popular brasileira.

Conforme versa Muniz Júnior (1976), como a mais forte expressão da música popular brasileira, ou a maior forma de expressão musical do povo brasileiro, o termo "samba" aparece na literatura histórica, antropológica e sociológica, com mais de um significado. Nesse sentido, não se pode pensar numa visão única, isso porque:

\footnotetext{
Na busca da origem e do significado da palavra 'samba', verifica-se que muitas fontes são comuns a vários autores, o que levou a uma seleção das principais referências que podem colaborar para a compreensão desse fenômeno sócio-histórico-cultural. (SIQUEIRA, 2012, p. 18)
}

Em meio a toda essa variedade de considerações acerca do samba, algumas apresentadas aqui poderão ir de encontro a outras correntes, contudo, entendese que estarão mais próximas do samba das margens do Velho Chico na região de Xique-Xique. Por isso, para que se possa entender melhor o que se postula teoricamente, convém, então, apresentar a seguinte cantiga do samba de roda "É na pisada ê": 
Dançou, dançou, piranha

Tornou dançar, piranha

Com a mão na cabeça, piranha

Com a mão na cintura, piranha

Dá um jeitinho no corpo, piranha

E uma umbigada na outra, piranha

Enquanto cantam e dançam essa cantiga, bem como em praticamente todo o tempo que o samba acontece, as sambadeiras encontram-se dispostas em um grande círculo, sambando ao ritmo das palmas e de instrumentos tocados, geralmente, pelos homens, os quais poucas vezes entram na roda para sambar. Sempre, ao centro da roda, uma sambadeira ensaia seus passos, demonstra sua ginga, ao ritmo de uma batida sincopada, marcada ora de forma pausada ora mais acelerada. Ao final, depois de executar vários passos, dirige-se a outra integrante da roda, dando-lhe uma umbigada, sendo que esta passa a substituí-la no meio do círculo.

Esse gesto de bater o umbigo no outro é muito comum nas apresentações de várias cantigas do grupo, prática que, segundo Cascudo (2008), recebe o nome de "semba" e tem procedência africana. Nesse ínterim, segundo Siqueira (2012), dentre as obras de referências específicas, a Enciclopédia da música brasileira: erudita, folclórica e popular também traz samba como provável procedente do quimbundo "semba" (umbigada), que designa dança de roda.

Sendo assim, não se pode desconsiderar a relação com as danças trazidas pelos negros, como o batuque e outros gêneros. Os passos, o posicionamento em círculo, os giros e umbigadas, dentre outros aspectos, fazem parte dessas danças, as quais, conforme Cascudo (2008), recebiam dos portugueses a denominação genérica de batuque, que assim nomeavam todas as danças de negros na África.

Coadunando com Marcos Antônio Marcondes, autor da obra Enciclopédia da música brasileira: erudita, folclórica e popular, reforça-se, portanto, a ideia de "samba" como um termo originado de "semba" e, inicialmente, sinônimo de "batuque", sendo que tanto "samba" como "batuque" foram termos utilizados para representar a dança dos negros no Brasil. Em uma das definições trazidas na respectiva enciclopédia, Marcondes (1977, p. 683) define samba como "palavra provavelmente procedente do quimbundo "semba" (umbigada), empregada para designar dança de roda (de coreografia semelhante à do batuque) popular 
em todo o Brasil, geralmente com dançarinos solistas, aparecendo quase sempre a umbigada".

Para que se possa compreender melhor essa relação, basta considerar o batuque como:

Dança considerada originária de Angola e do Congo (África). Sinônimo de batucada, é talvez a dança brasileira de mais antiga referência, tendo sido assinalada no Brasil e em Portugal já no séc. XVIII. É realizada em roda, da qual participam não apenas os dançarinos, mas também os músicos e os espectadores [...] No centro da roda, fica um dançarino-solista ou um ou mais pares que se incumbem da coreografia. Consiste em forte marcação pelos quadris, sapateados, palmas e estalar dos dedos. Apresenta como elemento específico a umbigada - que o dançarino ou os dançarinos-solistas dão nos figurantes da roda escolhidos para substituí-los [...] A palavra deixou de designar uma dança particular, tornando-se, como o samba, nome genérico de determinadas coreografias ou danças apoiadas em forte instrumental de percussão. (MARCONDES, 1977, p. 89)

Diante dessa profusão de definições, considerações e qualificações para o samba, a ideia que se pretende considerar aqui, por ser aquela que mais se aproxima da poética do samba de roda das margens do Velho Chico é a de uma prática cultural que envolve o canto e a dança, de extraordinária riqueza quanto aos elementos musicais, à melodia, ritmo e coreografia, em que se misturam e se adaptam marcas e influências africanas, europeias e ameríndias.

Depreende-se que o samba surge em meio a rituais comemorativos, religiosos e pagãos e traz, em si, uma pluralidade de ritmos e coreografias com cantigas carregadas de lirismo e poesia, cujos versos representam um universo, às vezes particular, e às vezes da coletividade social. As suas letras - compostas de sentimentos, desejos, crenças, valores, ideologias, fé e religiosidade - são capazes de retratar o cotidiano e a história de uma gente. Na sequência, como se pode observar numa das cantigas do grupo, há a representação de sentimentos e desejos que fazem parte do universo individual, particular.

Chora, viola, chora

Chora, viola da mina 
Vai dizer àquele ingrato

Que eu ainda estou na mesma sina

Se eu soubesse quem tu era

Ou quem tu haverá de ser

Não dava o meu coração

Para hoje eu padecer

Chora, viola, chora,

Chora, viola da mina

As rodas de samba, como já foi apontado antes, podem ser encontradas em praticamente todo o estado da Bahia, e essa presença chega até as margens do São Francisco na região de Xique-Xique, através de vários grupos de samba dispostos pelas diversas comunidades da beira do rio. Dentre eles, destaca-se o samba de roda do grupo "É na pisada ê".

Como se tem conhecimento em vários estudos, inclusive aqueles apresentados por Marcondes (1977), o samba se diversifica em vários tipos, de acordo com as suas características e história, a saber: samba de breque, samba-canção, samba carnavalesco, samba choro, samba enredo, samba de gafieira, samba de partido-alto, samba de quadra, dentre outros.

O gênero que atrai o interesse, por ser o objeto de estudo desta obra, é o samba de roda. Este, ainda de acordo com o Dossiê do samba de roda do Recôncavo baiano (2006), pode ser definido como uma reunião, com data fixada ou não, de grupo de pessoas para a performatização de um repertório musical e coreográfico. O respectivo dossiê também apresenta, de modo geral e resumido, as suas principais características, a saber: a) A disposição dos participantes se dá em círculo ou formato aproximado, donde se origina o nome; b) Presença de instrumentos musicais membranofones (como o pandeiro e o tambor), idiofones (como o prato-e-faca e as tábuas) e cordofone (como a viola, especialmente). Os tocadores, geralmente homens, ficam juntos na roda com os demais participantes, os quais ainda fazem o acompanhamento musical com palmas, de acordo com certos padrões rítmicos e ostinatos; ${ }^{11}$ c) Os cantos são estróficos e silábicos

11 No caso da cantiga da piranha, a expressão "piranha", que se repete entre os versos, pode ser considerada como uma espécie de ostinato, por acabar estabelecendo um padrão rítmico. Ostinato, segundo o Dossiê do samba de roda do Recôncavo baiano (2006), é considerado como um padrão (ou desenho) 
em língua portuguesa e de caráter responsorial e repetitivo. As estrofes são relativamente curtas e raramente ultrapassam oito versos, sendo que há ainda a ocorrência eventual da improvisação verbal; d) Apresenta coreografia variada, sempre dentro da roda, mas com predominância do gesto típico chamado de miudinho, feito sobretudo, da cintura para baixo e que consiste num quase imperceptível sapatear para frente e para trás dos pés quase colados ao chão, com a movimentação correspondente dos quadris. Embora os homens, algumas vezes, também possam sambar na roda, a predominância é das mulheres, já o manuseio dos instrumentos é atribuição dos homens. Há, ainda, a alternância de sambadores, pois, em geral, apenas uma pessoa samba ao centro da roda e finaliza a sua participação ao se dirigir a outro participante, geralmente com o gesto da umbigada; e) Pode acontecer dentro de casa, ao ar livre, em praças, terreiro de candomblé, em qualquer lugar. Sua performance possui caráter inclusivo e todos podem participar com palmas, cantando os refrãos e até sambando na roda.

Diante disso, percebe-se que tais características aferidas pelo Dossiê do samba de roda do Recôncavo baiano (2006) para qualificar, de uma forma geral, o samba de roda podem perfeitamente ser utilizadas para a descrição do samba do grupo “É na pisada ê". Praticamente tudo o que foi apresentado nessa caracterização pode ser aplicado ao samba do respectivo grupo, como se estivesse descrevendo, apresentando as suas próprias características.

Quanto à roda - forma pela qual se agrupam os integrantes para sambar e que, inclusive, qualifica esse tipo de samba, considerada como uma das suas principais marcas -, não se pode afirmar que, assim como a umbigada, seja exclusivamente trazida pelos africanos, pois, como versa Cascudo (2008, p. 592), "os portugueses e os africanos trouxeram as suas danças de roda, mas os indígenas também tinham as suas. Nenhuma novidade maior, porque a informação sobre as danças de roda é milenar”.

Outros autores também coadunam com tal ideia, contudo, tendo o samba de roda surgido a partir de práticas afrodescendentes, na maioria dos casos, podese considerar esse tipo de disposição em círculo como advindo dos povos de origem africana. Embora, em algumas danças específicas incorporadas ao samba,

rítmico que se repete com regularidade. De acordo com os dicionários de música, ainda se pode definir o ostinato como uma espécie de som repetido ou um padrão de som, que pode ser de natureza verbal, rítmica, textural ou tonal, com o intuito de proporcionar uma estrutura de conjunto harmônica ou rítmica. 
como no caso deste grupo estudado, o formato circular pode provir dos portugueses e indígenas.

Uma das marcas trazidas pelo Dossiê para caracterizar o samba de roda, como já foi apontado, é o miudinho, o qual é considerado como o passo mais característico do samba de roda, ressaltando que:

Trata-se de um leve e rápido pisoteado com os pés na posição paralela e solas plantadas no chão. No caso das sambadeiras, parece ser sempre a partir deste pisoteado que as outras partes do corpo se movem, simultaneamente, e a dança se desdobra. Embora o passo do miudinho seja, em amplitude, pequenino, ele proporciona locomoção cômoda devido à velocidade na qual é executado. Esta locomoção, ademais, pode ser feita para qualquer direção sem sair do miudinho: para frente, para os lados, ou para trás, de acordo com o desejo da sambadeira. (SAMBA..., 2006, p. 53)

Esse "elemento coreográfico, dançado pelas mulheres: o miudinho" (MARCONDES, 1977, p. 684) é também muito comum em todas as rodas de samba do grupo "É na pisada ê", contudo, recebe outro nome pelos seus integrantes: a pisadinha. Essa espécie de gingado é performatizada de maneira semelhante por todas as sambadeiras do grupo e, por ser tão presente nas rodas de samba, acabou servindo de inspiração para a criação do nome do próprio grupo: "É na pisada ê". Em todas as danças e performances, esse tipo de passo encontra-se presente, sendo que todas as sambadeiras o dominam com uma peculiar maestria. Elas cantam, dançam, giram, euforicamente, na roda, tendo a pisadinha como a sua maior marca.

Como uma marca comum do samba de roda, o miudinho, Esse tipo de passo ou pisoteado - que embora para o grupo seja mais conhecido como pisadinha aparece também denominado de miudinho em algumas de suas cantigas como a que segue:

Dançadeira que quer

Dançar tão miudinho

Se não dança ao meu gosto

Dance mais um bocadinho 
Na respectiva cantiga anteriormente citada, o miudinho é trazido como uma maneira que a "dançadeira quer dançar", isto é, à maneira tradicional do samba, a qual, para ser boa sambadeira, é preciso dominar essa espécie de pisoteado e, assim, dançar ao gosto de quem a observa, que poderá ser um dos seus pretendentes, pois esse é o momento da exibição e da conquista.

Assim como a pisadinha, outra característica comum dentro do samba do grupo é a umbigada, também usada com frequência pelas sambadeiras, as quais se utilizam desse gesto para convidar outra participante a cair na roda, funcionando como uma espécie de ritual, já que a sambadeira entra na roda após receber a umbigada e, ao sair, escolhe alguém fazendo o mesmo. Isso pode ser observado também na cantiga da piranha, que traz, no próprio verso, a alusão ao gesto da umbigada:

Dançou, dançou, piranha

Tornou dançar, piranha

Com a mão na cabeça, piranha

Com a mão na cintura, piranha

Dá um jeitinho no corpo, piranha

E uma umbigada na outra, piranha

As duas cantigas supracitadas também demonstram outra característica comum ao samba de roda, trazida no respectivo dossiê: a construção estrófica e silábica. (SAMBA..., 2006) Já na cantiga apresentada a seguir, vê-se o caráter de improvisação, pois enquanto os versos são cantados, pode-se improvisar, acrescentando mais atribuições à mulher que está doida, à medida em que são lembrados outros afazeres que ela tem que executar em sua lida diária. Há, ainda, a repetição de versos ou parte deles que ocorre tanto na cantiga anterior quanto nesta que se apresenta:

Essa mulher tá doida, tá doida tá

Essa mulher tá doida, tá doida tá

A mulher lava a roupa doida

A mulher pega a água doida

A mulher pega a lenha doida

A mulher lava os trem doida 
Essa mulher tá doida, tá doida tá

Essa mulher tá doida, tá doida tá

Nas apresentações do samba do grupo, é possível observar a disposição em círculo com uma sambadeira ao centro e ainda a presença dos homens tocando os instrumentos, enquanto os demais integrantes acompanham através das palmas. Assim sendo, tomando os exemplos apresentados, pode-se confirmar a inclusão do samba do referido grupo na tipologia de samba de roda, visto que apresenta uma proximidade muito expressiva no que concerne à caracterização desse tipo de samba.

O samba de roda do grupo "É na pisada ê" é, portanto, uma mistura de poesia, música e dança, a qual ocorre em uma espécie de círculo, sendo acompanhada pelo som de violas, pandeiros, caixas, tambores, chocalhos, triângulos, pedaços de madeira e das palmas das sambadeiras e sambadores. Além desses, atualmente, na apresentação de suas rodas, o grupo já dispõe de guitarra, violão elétrico, microfone e caixa amplificada.

Nota-se que as formas culturais, as quais se assemelhavam com o samba de roda na configuração de hoje, são encontradas em diversos registros históricos e estão sempre associadas ao universo dos negros, desde o século XVII, inclusive trazendo a umbigada e a disposição em círculo como marcas latentes.

Mas, conforme o Dossiê do samba de roda do Recôncavo baiano (2006), somente em 1838, num jornal satírico editado em Pernambuco, houve a primeira menção registrada no Brasil da palavra "samba", mas feita de passagem, sem nenhuma descrição ou associação específica aos povos de origem africana. Já na Bahia, o primeiro registro foi encontrado pelo historiador João José Reis, na cidade de Salvador, no ano de 1844, em relato de um carcereiro da prisão municipal ao seu chefe de polícia, no qual usava a expressão "samba de africanos ou de nacionais”. Contudo, tal registro não traz uma ideia do sentido exato da palavra "samba" empregado naquele momento pelo tal carcereiro.

Por volta da primeira metade do século XIX, de maneira genérica, como já foi dito antes, as diversões e demais danças dos negros eram chamadas de batuque. Somente a partir da segunda metade do referido século, conforme o Dossiê do samba de roda do Recôncavo baiano (2006), é que se passa a encontrar, sobretudo na imprensa e em registros policiais, referências em profusão ao samba da Bahia com as características presentes hoje, no samba de roda. 
Desde então, o samba, cada vez mais, foi incorporando-se às práticas culturais da sociedade baiana, especialmente, da região do recôncavo. Transpôs as fronteiras da Bahia e do Nordeste, chegando até outros lugares como o Rio de Janeiro, porém acrescentando outras características, assumindo novas influências e configurações, pois, conforme versa Carneiro (1961, p. 6),

\begin{abstract}
O samba de roda, transplantado da Bahia, comunicou os seus ritmos e o seu nome ( $s a m b a)$ à canção popularesca vigente no Rio de Janeiro e à dança social que lhe corresponde, mas também manteve a sua individualidade no partido alto e no samba, danças de umbigada das escolas de samba.
\end{abstract}

Observa-se, mediante a diversidade de informações trazidas pelos estudiosos em suas inúmeras obras, que o samba como gênero musical constitui-se a partir de uma confluência de ritmos, culturas e situações específicas, as quais contribuíram para uma variedade de gêneros e ainda de hipóteses sobre o seu surgimento e constituição em meio a essa pluralidade rítmica e performática. Segundo Marcondes (1977, p. 683), “os sambas mais conhecidos são os da Bahia, Rio de Janeiro e São Paulo”.

Sendo assim, dentre os vários cursos tomados pelo samba de roda no decorrer de sua história, segue-se agora pelas águas do Rio São Francisco, responsáveis por conduzir essa manifestação cultural até a região de Xique-Xique, onde assumiu também um jeito particular, uma nova aparência, devido às influências de uma nova terra e de uma nova gente.

Navegando pelas águas do Velho Chico, o samba de roda chega juntamente com a gente que desembarcava nas imediações da Ilha do Miradouro durante o seu processo de povoamento e de estabelecimento da cidade de Xique-Xique, e vai se configurando como prática cultural dentro das comunidades ribeirinhas. Em meio a essa ambiência plural, de riqueza de povos e culturas, a poética oral ribeirinha passa a tomar forma, e os grupos de samba começam a ocupar um lugar de destaque, entre as manifestações da cultura popular das margens do Velho Chico, dentre eles, em especial, o samba do grupo "É na pisada ê".

Segundo depoimentos dos próprios integrantes, em especial, da sra. dona Anita, a principal solista do grupo e guardadora dessa tradição, o samba de roda, que hoje recebe o nome de "É na pisada ê", existe desde o ano de 1938, tendo 
como o seu fundador o sr. Manoel Por Baixo, avô de dona Anita, a qual herdou a tradição desse samba, mantendo-o até os dias de hoje.

Quanto ao apelido "Por Baixo” que acompanha o nome do seu avô, a própria dona Anita conta que todos os integrantes da família passaram a ser chamados assim, porque todas as vezes que o pai do seu avô bebia cachaça com raízes dentro (prática comum dos moradores até hoje), costumava usar a expressão "É Deus por cima e nós por baixo”. A partir daí, todos começaram a chamar a família dos "Por Baixo".

Surgiu nas imediações do Bairro de Paramelos, inicialmente, tendo como participantes e organizadores o sr. Manoel Por Baixo e seus familiares. Nessa época, por volta dos anos de 1940, costumavam se reunir em grupo para as rodas de samba ao redor das fogueiras, especialmente, no período junino, para se confraternizar e comemorar a colheita de milho, de feijão e de outros gêneros. Nesse período do ano, na região, costuma-se colher as plantações feitas na estação das chuvas, geralmente, iniciada no final do ano, indo até abril.

Então, o mês de junho era o tempo da fartura, era tempo de comemorar e agradecer aos santos, como afirmam os próprios moradores: "A gente planta nos dias de São José e colhe nos dias de São João, quando o tempo é bom de chuva”. ${ }^{12}$ É também nessa época que há a produção de outros alimentos como as frutas, dentre elas, a laranja e a lima, as quais são citadas nas cantigas do samba do grupo.

Na noite do dia 23 para 24 de junho, acontecia a mais importante das festas, pois era a noite de São João, ao qual muitos tinham devoção, devido à influência da Igreja Católica no processo de colonização, fato que contribuiu para que muitas tradições chegassem de Portugal e se estabelecessem como práticas aqui no Brasil, inclusive nas margens do Velho Chico. Uma das cantigas do próprio grupo de samba serve para comprovar tal relação com a religiosidade e, em especial, com o São João e a sua festa, a qual, segundo os próprios versos, ocorre anualmente:

12 Na tradição católica, o dia de São José é comemorado em 19 de março, e o de São João, em 24 de junho. Assim, nesse período, entre os meses de março e junho, costuma-se plantar e colher alguns gêneros como o milho e o feijão que levam, geralmente, três meses para a produção dos grãos. 
Adeus, meu senhor São João

Até para o ano que vem

Se vós me emprestar a vida

Se vós me emprestar a vida

Quando for para outro ano

Eu venho, senhor São João

Ontem eu disse

Hoje torno a dizer

Quem tiver suas promessas

Cuide logo em fazer

Adeus, meu senhor São João

Até para o ano que vem

Meu senhor São João foi embora

De muda pela glória

De muda pela glória

Quem me dera ir com ele

Quem me dera ir com ele

Dentro do seu oratório

Adeus, meu senhor São João

Até para o ano que vem

Se vós me emprestar a vida

Se vós me emprestar a vida

Viva, meu senhor São João

Com o crescimento do bairro e a chegada de outras famílias na região, o samba foi se tornando mais forte, agregando outros participantes e se fazendo presente em diversos momentos da vida cultural da comunidade. As rodas de samba do Bairro de Paramelos (como ainda era conhecido) tornaram-se cada vez mais frequentes, passando a ser um momento de encontros e de celebrações entre as pessoas da comunidade, as quais se reuniam para comemorar a boa pescaria, as colheitas, os nascimentos, os casamentos, dentre outras atividades, também por ocasião das festas religiosas. 
E cada vez mais, devido à grande religiosidade das pessoas da referida comunidade, as rodas de samba foram sendo motivadas pelo aspecto religioso, ocorrendo por volta das celebrações católicas do dia de Reis, dos santos padroeiros São José, Santo Antônio, São João, São Pedro, dentre outros. Isso porque, na colonização da região, houve a presença marcante da Igreja Católica e suas estratégias de evangelização, como a realização das Santas Missões, a catequização e a construção de capelas, dentre outras ações. Tal circunstância, contribuiu para que o samba de Paramelos, assim como em outras regiões da Bahia e do Brasil, mantivesse essa aproximação com a religiosidade, a reza, a adoração.

Sendo assim, tornou-se comum a associação do samba a uma espécie de dança religiosa, não somente para o catolicismo, mas também para as religiões de matriz africana. $\mathrm{O}$ ato de louvar, o ritual da dança em honra e adoração à divindade, presente nas cerimônias religiosas, é adotado pelas três principais etnias formadoras da cultura de nossa nação: ameríndia, europeia e africana. Nesse sentido, convém ressaltar que o samba aparece, muito comumente, associado com dança religiosa, dança ritual e dança da reza.

Vale ressaltar que, de acordo com depoimentos de membros do grupo "É na pisada ê", nas festas religiosas dos terreiros de candomblé existentes na região, há sempre rodas de samba, ${ }^{13}$ inclusive com a participação de alguns integrantes do grupo. Mas, segundo os depoentes, essas festas ocorrem de forma reservada dentro do terreiro, visto que, como se tem conhecimento, ainda existe muita discriminação para com as práticas religiosas de matriz africana em nossa sociedade. Isso ocorre devido ao afropessimismo implantado através da ideologia do embranquecimento que se pauta no desmerecimento do negro e suas práticas culturais e religiosas.

Contudo, esse tratamento subalternizante e excludente dado às práticas culturais e religiosas afrodescendentes não conseguem impedir que o samba, quando ultrapasse os limites dos terreiros, chegue até as praças, os pátios e demais espaços de convivência social, carregado de marcas e características desse

13 A dança sagrada dos candomblés não é considerada propriamente um samba, apesar de haver uma roda (o xirê), onde dançam os orixás manifestados e membros da religião. Mas, tanto nas comemorações profanas dos terreiros como em algumas festas sagradas específicas (a exemplo do culto, na umbanda, aos marujos, às pombagiras etc., em homenagem a essas entidades), é comum haver roda de samba. Há indícios, portanto, de que o termo "candomblé", empregado pelos depoentes, no contexto xiquexiquense, designe, de maneira genérica, as religiões de matriz africana ali existentes (candomblés e umbandas). 
viés tão forte dentro da cultura do "povo de santo", como assim são chamados os adeptos das religiões de matriz africana.

Da marginalidade a que é relegado pela maior parte da sociedade, esse samba chega trazendo elementos de sua tradição como os passos, os batuques, alguns adornos como as guias de santo, e outras espécies de vestimentas, muitas vezes, utilizadas em rituais particulares. É pertinente lembrar que, nas rodas fora dos terreiros, não se utilizam apenas os trajes e adereços exclusivos dessas cerimônias, mas alguns desses elementos aparecem mesclados às vestimentas comum do grupo.

É válido ressaltar ainda que, para este estudo, não se utilizaram as cantigas proferidas em cerimônias religiosas dos terreiros xiquexiquenses, nem se observaram as rodas de samba realizadas em seus rituais, visto que nem todos os integrantes do grupo "É na pisada ê" são praticantes das religiões de matriz africana ali existentes, mas apenas alguns, os quais mantêm uma certa reserva e sigilo quanto a isso, devido, sobretudo, ao próprio olhar discriminatório por parte da sociedade, da Igreja Católica e outros segmentos. Isso porque, conforme versa Góis (2008), a herança cultural e religiosa gestada no período colonial ainda persiste no preconceito, desconhecimento e não reconhecimento das tradições religiosas de herança africana.

Notam-se, nesses sujeitos - os membros do grupo -, a fé e o respeito às entidades sagradas e práticas dos terreiros, mas não gostam muito de falar a respeito, por medo de o grupo vir a sofrer alguma retaliação, como não poder se apresentar nas festas da Igreja Católica, participar de grupos musicais e outras atividades. Pois, nesse momento, tem-se iniciado um movimento de maior aceitação e integração do grupo por parte da Igreja Católica, o que será discutido com mais detalhamento adiante. Então os integrantes do grupo utilizam a estratégia do silenciamento, que se iniciou com a escravização do negro, diante da proibição de muitas de suas práticas culturais e religiosas.

Desde que aqui chegou, durante a colonização, o negro teve de aprender a conviver com situações desfavoráveis à sua cultura, religião e até mesmo à própria sobrevivência. O sistema social vem contribuindo, desde a colonização até os dias de hoje, com o processo de exclusão dos negros, causando, assim, desumanas condições de vida desses sujeitos. Por isso, na tentativa de não sofrer as consequências desfavoráveis dentro da sociedade, muitos afrodescendentes 
costumavam - e alguns ainda continuam - a negar a sua cultura e tradição, uma vez que:

O africano escravizado, com sua estranheza e diferença, era tanto mais aceito quanto mais negava e se distanciava de seus ritos e de sua cultura. Só na negação de si mesmo, ele podia ser reconhecido como gente, como pessoa, como humano. (GÓIS, 2008, p. 87)

Assim, como no caso de alguns integrantes do respectivo grupo de samba, a ressignificação de algumas práticas e até mesmo o silenciamento passaram a fazer parte da vida dos povos afrodescendentes. Contudo, determinadas marcas da cultura afrodescendente acabaram chegando até o samba de roda em estudo, como alguns componentes da vestimenta, instrumentos musicais, adereços, ritmos, passos e expressões verbais.

No que compete às letras das cantigas apresentadas pelo grupo em suas rodas de samba, nas festas de padroeiro ou demais momentos, pode-se afirmar que não trazem referências diretas a orixás ou rezas do candomblé. Apenas invocações e referências aos nomes de santos católicos são percebidas.

Mesmo assim, através dos elementos da cultura afrodescendente que se presentificam no samba do grupo, como os citados anteriormente, pode-se inferir que servem para demonstrar a diversidade cultural e religiosa que constitui a comunidade de sambadores, uma vez que, mesmo tendo roupas específicas para as apresentações nas rodas de samba, em algumas dessas apresentações, especificamente as mais particulares, isto é, que se realizam nas imediações do próprio bairro em que vivem os componentes do grupo, os trajes se compõem com mais evidência desses elementos da cultura de matriz africana, como o torço, as guias e as roupas brancas.

Geralmente, isso ocorre mais quando a roda de samba acontece como parte de alguma reza, caruru de Cosme e Damião ou festa de samba na casa de alguma pessoa da comunidade. Nessa circunstância, vê-se, de modo mais enfático, o uso de roupas brancas, guias, torços e até alguns outros símbolos que representam a cultura e as religiões de herança africana. Sendo assim, em momentos como esse, fica latente a convivência entre culturas diversas, nesse caso, a do colonizador (o branco) com a do escravizado (o negro). Nas apresentações, nos espaços e 
festas públicas e religiosas, os trajes são mais estilizados para a apresentação, na qual prevalecem a saia rodada de tecido florido e as blusas com o nome do grupo.

Inicialmente chamado de samba de Paramelos, por ter nascido nas imediações do bairro homônimo, o grupo de samba de roda "É na pisada ê" passou a se chamar assim, somente algum tempo depois. Como já fora justificado aqui, tal mudança de nome teve como inspiração essa espécie de pisoteado que se faz principalmente com os pés, chamada de sapateado, conforme já descrito antes neste estudo, mas que, na região, é conhecido por todos como pisadinha. É por isso que o samba recebeu o respectivo nome.

Quanto ao bairro de Paramelos, este recebeu tal nomeação como uma homenagem à primeira família a estabelecer residência na região. A família Paramelos foi uma das pioneiras na povoação do bairro onde hoje vive a maioria dos integrantes do grupo, bairro atualmente chamado de São Pedro.

Tendo nascido sob os cuidados do sr. Manoel por Baixo, um dos homens que possuíam certa notoriedade no bairro, com boas relações, inclusive por ser respeitado como um grande pescador e comerciante, o samba ganhou fama, e as suas rodas se tornaram cada vez mais frequentes dentro da comunidade, chegando a ser consideradas, na época, como uma grande oportunidade de interação entre as pessoas de famílias, bairros e até localidades vizinhas.

As rodas de samba do grupo passaram a ser tidas como grandes acontecimentos sociais, pois reuniam gente de toda a região. Os próprios integrantes do grupo contam que muitos casamentos se deram a partir desses encontros, o comércio se fortaleceu, contribuindo para o crescimento da economia local. Porém, com o passar dos tempos, devido ao envelhecimento do sr. Manoel por Baixo, considerado um grande incentivador da arte e da cultura na comunidade, o samba foi perdendo força, e as suas rodas passaram a acontecer com bem menos intensidade, ficando relegadas ao interior das casas de alguns de seus integrantes. Essas rodas de samba passaram a acontecer em ambientes fechados, de forma reservada e sem a grande expressividade de outrora.

Tal realidade só permaneceu assim até o início da década de 1990. Com o falecimento do seu criador, a sua neta, dona Anita, uma senhora que hoje se encontra com quase 80 anos, assumiu o posto de líder e incentivadora do grupo. Com isso, a realidade começou a mudar e, sob o olhar inovador de uma deficiente visual, o samba do grupo "É na pisada ê" voltou a brilhar, ganhando um novo posto dentro da comunidade. 
Dona Anita é anciã e deficiente visual, não enxerga, mas traz, em sua memória, as cantigas e os passos das suas danças. Juntamente com outros integrantes do grupo, vem fortalecendo gradualmente as tradições da comunidade, por meio da poética do seu samba de roda. Dona Anita age como uma grande incentivadora da cultura popular, fazendo, hoje, as vezes de seu avô em tempos passados. É ela quem coordena e organiza as rodas e as cantorias, bem como ensina a maneira de se dançar algumas coreografias e passos, o modo de se cantar as letras das cantigas. Nas apresentações, comanda a roda e puxa o samba na maioria das vezes, agora, utilizando caixa amplificada e microfone, evidenciando a sua participação. É ela uma das principais solistas, já que, por diversas vezes, adentra na roda para puxar o ritmo, a cantiga, a dança.

Costuma-se dizer que "dona Anita enxerga com os olhos da alma”, pois quem não a conhece, ao vê-la dançar e cantar na roda, jamais imagina que ela seja deficiente visual. Dona de um sorriso permanente, a principal motivadora do grupo traz consigo a felicidade e o orgulho, por ver o seu grupo cada vez mais vivo, mais fortalecido. Está sempre estimulando todas a gerações (crianças, jovens, adultos e idosos) para cair na roda. Na figura de dona Anita, traduz-se o papel da mulher, sobretudo, anciã, na manutenção da memória negra, do legado cultural afrodescendente.

O grupo, atualmente, mantém-se sob a coordenação de dona Anita, auxiliada por suas companheiras e vizinhas sambadeiras. Como em outras práticas da cultura popular, as mulheres passaram a ter destaque dentro do grupo, e dona Anita, por meio da oralidade, é quem ensina as coreografias, repassa as letras e os ritmos das cantigas, conta histórias, enfim comanda, em tom griótico, todas as suas atividades. Sim, pode-se dizer que dona Anita é uma espécie de griote (à moda brasileira) do grupo, pois, apesar de lhe faltar a visão, conecta oralidade e performance, assumindo o papel de guardiã e transmissora do patrimônio cultural (imaterial) daquele grupo. Na roda de samba, é ela quem direciona o andamento da "brincadeira", como os próprios integrantes costumam chamar a roda de samba, atuando, também, como a dançarina-solista de mais expressividade.

Conforme Barzano (2013), griote é o feminino de griot, uma palavra de origem francesa, de uso habitual no noroeste da África, na região do Mali, cuja colonização foi feita pela França. Já o termo "griótica", originado do francês griotique, foi criado e inicialmente usado no teatro africano. Como versa Queiroz (2007, f. 109): 
O termo griotique, de acordo com a perspectiva sinalizada por Niangoran Porquet, antropólogo e dramaturgo costa-marfinense, traduzia um conceito literário e artístico de teatro apresentado como representativo de especificidades do teatro negro africano. Ao espelhar-se na arte performática griot, a experiência griotique reivindicou uma síntese entre poema, drama e narrativa curta, estabelecendo, portanto, um 'teatro total', resultante da integração entre o verbo, a expressão corporal, a música, a poesia, a dança e a recitação.

Convém ressaltar que a expressão “oralidade" vai além do significado banalizado de seu termo, mas uma oralidade que exige interlocutores, ação, mediação e recepção, como ocorre em todos os momentos das apresentações do samba de roda. Oralidade, pode ser entendida, portanto, como vocalidade, assim como versa Zumthor (2005, p. 141, grifos do autor):

A presentificação performancial de um enunciador e de seus ouvintes implica uma mediação que (na acepção corrente da palavra performance) é vocal. Assim, não me contento em remeter ao que designa o termo banalizado oralidade (o fato bruto de que o meio não é a escrita e provoca uma percepção auditiva). Falo de vocalidade, evocando através disto uma operação não neutra, veículo de valores próprios, e produtora de emoções que envolvem a plena corporeidade dos participantes.

Quando dança, a velha Anita enlaça a música e a poesia em seu corpo, numa espécie de pedagogia performática do samba de roda ribeirinho - atravessada pela marcação oral da poética que emerge do Velho Chico, a qual ancora a memória do seu povo - incentivando a perpetuação dessa manifestação cultural nos corpos e na oralidade dos mais jovens. Eis o seu papel de griote, compreendido a partir do livro autobiográfico Amkoullel, o menino fula (2003[1992]), de Amadou Hampâté Bâ, que apresenta uma teoria sobre a arte narrativa e performática do griot - abordagem imprescindível ao entendimento da magnitude dessa herança antigrafocêntrica para o legado cultural afrodescendente.

As mulheres são maioria e se destacam na roda de samba com seus passos, seus requebros, suas pisadinhas e saias rodadas. Ao lado de dona Anita, uma outra mulher vem se destacando em frente ao grupo: a professora Giselda 
Pinheiro Meira, ou simplesmente Del, como é chamada carinhosamente por todos. Enquanto se encontrava à frente do Departamento de Cultura da Prefeitura Municipal de Xique-Xique, nos últimos anos, iniciou um trabalho de valorização e incentivo ao grupo.

A professora Giselda e dona Anita estão, atualmente, à frente da coordenação do grupo. Del integra-se ao grupo não apenas como sambadeira, mas tocando viola e, às vezes, puxando as cantigas. Como aluna do curso de Especialização em Estudos Linguísticos e Literários da UNEB, em Xique-Xique, Giselda desenvolveu também um trabalho monográfico de conclusão de curso, baseado em uma pesquisa sobre o grupo.

A partir do ano de 2009, por meio das atividades de extensão desenvolvidas pelo Departamento de Ciências Humanas e Tecnologias da UNEB do campus de Xique-Xique, o grupo passou a ter mais expressividade dentro da comunidade xiquexiquense. Convidado para apresentar a sua roda de samba nos referidos eventos da universidade, o grupo passou cada vez mais a ser conhecido e valorizado, inclusive chegando a receber ajuda de custo de alguns setores públicos, a exemplo da Pró-Reitoria de Extensão (Proex) da UNEB, para a compra de instrumentos, confecção das vestimentas e de outros acessórios.

Dessa forma, depois das apresentações nos eventos da UNEB em XiqueXique, começaram a surgir convites para se apresentarem nas escolas, feiras de cultura, e outras festas, tanto na cidade de Xique-Xique quanto em cidades circunvizinhas. A cada dia, o grupo vem ganhando mais notoriedade dentro do cenário cultural regional e até mesmo nacional. O grupo já se apresentou em alguns programas de TV, tanto no âmbito regional quanto de alcance nacional, a exemplo da participação no programa Globo Rural, da Rede Globo de Televisão.

Devido ao trabalho efetuado com a cultura popular tanto no, campus XXIV da UNEB, em Xique-Xique, quanto pela prefeitura municipal e outros projetos de fomento e valorização à cultura local, o grupo e suas tradições vêm cada vez mais se fortalecendo. Tais ações também têm contribuído para o aumento da autoestima dos integrantes do grupo. Atualmente, a grande evidência do grupo dentro da comunidade serve de motivação para as mais novas gerações de sambadeiras e sambadores. Antes, havia uma certa resistência dos mais jovens, os quais não se sentiam à vontade para sambar nem participar das rodas. Agora, todos querem fazer parte do grupo e integram, orgulhosamente, as rodas de samba. Por isso, o samba atualmente, possui integrantes de diversas faixas etárias: 
desde crianças a partir de dois anos de idade até anciãos de, aproximadamente, 90 anos.

O lugar de destaque no grupo é das mulheres, e os homens ocupam um papel secundário, mas também importante, pois são eles que tocam com habilidade e maestria a maioria dos instrumentos utilizados no samba. Algumas vezes, entram na roda e fazem alguns giros e pisadas, embora não seja uma prática que perdure muito tempo, pois não é comum fazerem o papel de solista. Ficam mesmo compondo a roda, batendo palmas ou tocando os instrumentos.

Há uma certa vaidade em cada um dos integrantes do grupo, que, hoje, conta com aproximadamente 80 sambadeiras e sambadores das mais diferentes faixas etárias. Mas as mulheres são mais vaidosas do que os homens, pois, quando vão à "brincadeira", como é de costume se chamar a roda de samba, investem muito mais na aparência e na composição do vestuário. Enquanto os homens se limitam ao uso de calça, de uma camisa e, às vezes, de um chapéu (hábito comum entre os moradores da região), as mulheres usam roupas coloridas com longas e rodadas saias estampadas de flores, colares, pulseiras e brincos coloridos e, também, costumam prender o cabelo com flores ou laços de fitas.

Estão sempre usando perfumes e maquiagens, especialmente o batom, sem se esquecer das unhas pintadas. Assim, para as mulheres, o dia em que tem roda de samba é dia de grande alegria, de ficar bonita e cheirosa, pois é um momento de encontrar amigos e - principalmente para as jovens solteiras - hora de paquerar, de se fazer notar pelo gingado dos quadris, pelo ritmo da pisadinha, visto que a roda de samba não deixa de ser um grande palco, onde a sambadeira tem o seu momento de solista na roda para se exibir e demonstrar a sua dança, beleza e graça.

Como já foi dito, compete aos homens tocar a maioria dos instrumentos, mas é comum as mulheres utilizarem dois pedaços de tábuas, sendo que, ao bater uma na outra, extraem uma espécie de som, o qual dá ritmo às cantigas. Esses vários tipos de instrumentos tocados pelo grupo servem também para ilustrar, na poética oral ribeirinha, o encontro entre várias culturas, pois a viola e o violão chegaram em nosso meio, pelos portugueses, já os tambores foram trazidos pelos africanos.

Nas rodas de samba, há o predomínio da espontaneidade na maneira como todos se apresentam. É um momento de grande alegria e descontração, no qual todos se envolvem e participam cantando, sambando, girando, batendo palmas 
ou tocando instrumentos. A roda de samba está presente em praticamente todas as atividades culturais e demais festejos regionais. Seja do âmbito profano ou religioso, a tradição da roda de samba vem se tornando, cada vez mais, expressão festiva do universo ribeirinho. Desde um batizado, casamento, aniversário, pescaria ou festa de padroeiro, tudo leva o povo das margens do Velho Chico a cair no samba.

A poética do samba de roda, dentre as diversas manifestações que compõem o cenário cultural das margens do Velho Chico, ocupa uma posição precípua, tornando as suas rodas e apresentações cada vez mais costumeiras e tradicionais nos festejos e demais celebrações da região, confirmando a assertiva de que, numa comunidade, "todos os acontecimentos podem dar motivo para um samba, seja um batizado, uma reunião espontânea dos moradores do povoado etc”. (PINTO, 1990, p. 108)

A história do samba de roda do grupo "É na pisada ê" e suas características se aproximam das dos demais grupos desse mesmo gênero, porém com uma identidade particular que lhe confere um retrato diferenciado dos demais, devido, entre outros fatores, ao processo de colonização e de formação de sua gente. 